\title{
DETERMINATION OF THE OPTIMIZING FUNGICIDAL APPLICATIONS FOR CONTROLLING APPLE SCAB DISEASE IN EGYPT
}

\author{
M. A. Radwan and M. S.S. Hassan \\ Plant Pathol. Res. Inst., Agric.Res. Center, Giza, Egypt \\ drmahmoudawwad67@yahoo.com\& mabrouk2276@yahoo.com
}

Received: Feb. 27 , 2019

Accepted: Mar. 17,2019

\begin{abstract}
Apple scab caused by Venturia inaequalis (Cooke) G. Wint., is the most serious fungal disease affecting apple trees in many apple production areas of the world and Egypt, that resulting in the defoliation of trees and making the fruits unmarketable. Depending on the risk of disease, 8 to 10 or even more fungicidal applications usually need for efficient control. If the disease is not controlled at the suitable time of application, the disease can affect $70 \%$ or more of the yield. Field studies were conducted during 2017 and 2018 growing seasons in two districts of two Governorates of Egypt, i.e. Qalyoubia at El-Qanater El-Khayria Horticultural Research Station, Agricultural Research Center, and Beheira at a private farm at Kafr EI Dawar. The efficiency of different tested fungicides and the time of their application (four variable times) on controlling the disease and fruit yield production were estimated. Time of application have markedly affected the efficiency of the fungicides that used. Disease suppression and fruit yield (kg/tree) were greater when the tested fungicides were applied at the third application program (at fruit set in the first week of April when the first symptoms of scab infection were observed), followed by the second application program (at full bloom in the first week of March), while fungicide applications at the first application program (at bud burst in the first week of February) and the fourth application program (at fruit growth in the first week of May) recorded the highest disease severity\% and the lowest yield productivity ( $\mathrm{kg} / \mathrm{tree}$ ) in the two governorates through the two growing seasons. Bellis, Amistar top and Score had more effect on apple scab infections and yield productivity (kg/tree), followed by Occidor, Topsin $M$ and Namrod but the lowest efficiency\% and the lowest productivity of yield (kg/tree) were recorded with Dithane $M$, Index, Copper oxychloride and Microvit through 2017 and 2018 growing seasons in the two governorates. Sulphur and copper, however, gave acceptable control for apple scab when used at an appropriate time.
\end{abstract}

Key words: Apple scab,Venturia inaequalis, fungicides and application times.

\section{INTRODUCTION}

Apple (Malus domestica Borkh) is the most important, widely and a highly appreciated and commercially cultivated fruit crop after citrus, grapes and banana. Anna apple is the most popular cultivar grown in Egypt. The cultivated area in Egypt reached about 71489 Feddan (Feddan $=0.42$ Hectare), which produced about 541239 metric tons (Anon., 2017). Apple scab, caused by the fungus Venturia inaequalis, is the most important disease that has invaded all apple-growing regions around the world. It has negative effects on the economy due to the impact of yield losses, the use of fungicide inputs, and with the corresponding environmental and health hazards (Gladieux et al., 2008). It survives the winter in the infected leaves and fruits fallen from the trees. Apple scab causes deformation in affected fruits and causes premature leaf and fruit fall (Thakur et al., 2013). The apple scab 
infections do not kill the tree but result in leaf and fruit loss. The disease can affect $70 \%$ or more of the yield if control measures are not applied well (Agrios, 2005). Yield and quality losses in the Netherlands caused by apple scab are estimated to be around $80 \%$ if no control measures were taken (Holb et al., 2003). Besides the direct loss in fruit, apple scab can severely weaken the viability of trees for next season since infections, reduce photosynthesis, woody growth is limited, and fruit bud initiation is prevented or reduced (Jamar et al., 2010). Apple scab can lead to severe crop losses if it is not controlled properly (Gusberti et al., 2012). Fungicide application remains the primary tool for managing this disease. Depending on weather and disease pressure, up to 15 protectant fungicide spray applications may be necessary to control this disease on susceptible apple cultivars (Jamar et al., 2010). Sprays are routinely applied from bud burst at 7-10 day intervals until the risk of scab ceases. Protectant fungicides are used early in the season when there are only a few leaves or when an infection period can be forecasted. Curative fungicides are used when a protectant fungicide applied before the infection was washed off by rain, a protectant fungicide was not applied prior to the infection period, or the risk of primary infection was very high (Jobin and Carisse 2007). Infection is initiated in spring by ascospores that are released by rainfall from pseudothecia (Bowen et al., 2011). In California, periodic applications of synthetic or organic fungicides from approximately March to June are required to control apple scab; the timing of fungicide applications is dependent on season to season patterns in precipitation (Gubler, 2006). The disease is generally controlled by the repeated application of fungicides directed against ascospore infection. When the ascospore supply is depleted in early summer, the interval between fungicide sprays increases and, in some cases may not be necessary (Mac Hardy, 1996). Successful management of apple scab is dependent on application time to minimize the negative impacts of fungicide applications. The number of treatments could be reduced to 4 applications, using fungicides at the suitable time.

The aim of this investigation is to keep the losses from apple scab disease to a level that does not represent a threat to the crop production and to determine the best chemical control strategy for apple scab disease, according to optimal application times of some available fungicides, where fungicide management is the main tool to control this disease to provide useful information and extension services for the apple growers and advisers in Egypt.

\section{MATERIALS AND METHODS \\ Disease control.}

Effect of fungicides at different times of application on the severity\% of apple scab at Qalyoubia and Beheira governorates.

In 2017 and 2018 growing seasons, two field trials were carried out at the experimental apple orchard (cv. Anna, 12year old) located in El Qanater El-Khairia Horticulture Research Station, Agricultural Research Center, Qalyoubia governorate and a private farm (cv. Anna, 12- year old) in Kafr El Dawar, Beheira governorate to compare the effect of four application programs according to the time of application on the effectiveness of fungicides for controlling apple scab disease to choose one treatment program in order to reduce the amount of fungicide required. Also, this study was undertaken to evaluate the efficacy of ten preventative and curative applications of fungicides for controlling apple scab. At the beginning of the growing season, good pruning was performed to remove 
dead tissues and the over wintering leaves that play as inoculum source of the causal pathogen. Apple trees were fertilized, irrigated and sprayed to prevent insect injury for a healthy growth in the orchard. This experiment strongly depended on the time of application during the two successive seasons and was divided into four programs according to the time of application to reduce the number of the fungicide treatments. In the first application program, the tested fungicides were sprayed at bud burst (when leaf tips start to protrude from the buds) at the first week of February. In the second application program, the tested fungicides were sprayed at full bloom (when $50-75 \%$ of the blossoms are opened) at the first week of March. In the third application program, the tested fungicides were sprayed at fruit set (when $85-90 \%$ of the petals have fallen) at the first week of April. In the fourth application program, the tested fungicides were sprayed at fruit growth (20-25 days after fruit set) at the first week of May. In the control treatment the trees were sprayed with water. Three replicates were used for each treatment and five trees were used as replicates in each program. All the tested separately fungicides were sprayed four times at the 15- day interval. Among the fungicide evaluated, contact fungicides that inhibit fungal spore germination comprising of Microvit, DithaneM-45, Index and Copper oxychloride and systemic fungicides that retards spore movement and germination that include Amistar top, Bellis, Score, Topsin M70, Nimrod and Occidor were used in Table 1. For each fungicide, the recommended dose was applied to Anna apple trees. The trees were left to the natural infection by scab. Apple tree was carefully examined; four long shoots were selected randomly from four geographical directions of each tree and five leaves were selected randomly from each shoot and assessed for the presence or absence of scab in June and
July.The disease severity $\%$ was estimated depending on the modified scale (0-5) by Townsend and Heuberger, 1943 as follows:

$(0)=$ No scab observed (healthy leaf).

(1) $=1-10 \%$ of leaf area affected.

(2) $=11-24 \%$ of leaf area affected.

(3) $=25-50 \%$ of leaf area affected.

(4) $=51-74 \%$ of leaf area affected.

$(5)=75-100 \%$ of leaf area affected.

The severity of the disease was calculated using the following formula:

Disease severity $\%=\frac{\sum(\mathbf{n} \times \mathbf{v})}{5 \mathrm{~N}} \times 100$

Where

$\mathrm{n}=$ Number of the infected leaves in each category.

$v=$ Numerical values of each category.

$\mathrm{N}=$ Total number of the examined leaves.

Efficiency of spray treatments was estimated using the following formula:

$\%$ Efficiency =

$\frac{\text { Disease severity in control - Disease severity in treatment }}{\text { Disease }} \times 100$ Dis ease severity in control

Effect of fungicides at different times of application on the fruit yield (kg/tree) at Qalyoubia and Beheira governorates.

The effective study of a reflection of the four tested programs on fruit productivity of apple trees is evaluating productivity yield (kg/tree). The objective of this study was to evaluate the efficacy of ten preventative and curative applications of fungicides and to compare the effect of four application programs according to times of application on the fruit yield at Qalyoubia and Beheira governorates in 2017 and 2018 growing seasons. Three trees of each treatment (one tree per each replicate) were chosen randomly. The produced fruit yield was separately harvested in the harvesting period to estimate the average yield according to the weight of all harvested fruits $(\mathrm{kg} \mathrm{I}$ tree). 
Table 1. Trade names, active ingredients and application rates of chemicals.

\begin{tabular}{|c|c|c|}
\hline Trade name & Active ingredient & $\begin{array}{c}\text { Dosel } 100 \mathrm{~L} \\
\text { water }\end{array}$ \\
\hline Microvit KZ 80\%WP & Sulfur & $250 \mathrm{~g}$ \\
\hline Amistar top 32.5\% EC & $20 \%$ Azoxystrobin +12.5\% Difenoconazole & $60 \mathrm{~mL}$ \\
\hline Bellis 38\% WG & $25.2 \%$ boscalid+ $12.8 \%$ pyraclostrobin & $30 \mathrm{~g}$ \\
\hline Score 25\% EC & Difenoconazole $25 \%$ & $50 \mathrm{~mL}$ \\
\hline Topsin M70WP & Thiophanate methyl 70\% & $65 \mathrm{~g}$ \\
\hline DithaneM-45 80\%WP & Mancozeb80\% & $250 \mathrm{~g}$ \\
\hline Nimrod 25\%E.C & Bupirimate $25 \%$ & $40 \mathrm{~mL}$ \\
\hline Occidor 50\%SC & Carbendazim $50 \%$ & $150 \mathrm{~mL}$ \\
\hline INDEX 77\% WP & Copper hydroxide $77 \%$ & $250 \mathrm{~g}$ \\
\hline Copper oxychloride 80\%WP & Copper oxychloride & $300 \mathrm{~g}$ \\
\hline
\end{tabular}

Statistical analysis.

The obtained data were subjected to analysis of variance and significant differences among means, according to Snedecor and Cochran (1984). In addition, significant differences among means were distinguished according to the Duncan multiple tests range (Duncan, 1955).

\section{RESULTS}

Symptoms of apple scab.

The first symptoms of scab infection were observed at Kafr EI Dawar, Beheira governorate in April1 ${ }^{\text {st }}$ and at El Qanater El-Khairia, Qalyoubia governorate in $7^{\text {th }}$ of April and usually lasts six to seven weeks. The apple scab fungus does not kill the tree, but infection results in leaf and fruit loss. Apple scab infects foliage, blossoms and fruits. The symptoms are generally most noticeable and serious on leaves. During the main growth period in early spring, there is more susceptible tissues available for infection and therefore, greater risk of disease than later in the season. Both sides of the leaves can get infected. The first visible lesions on the leaves are often found on the lower surface of leaves in the spring and they are small, discrete, circular and dark olive-green lesions which later darken and become necrotized and eventually fall out. The spots can be seen on upper side later in the season. Symptoms on the upper surface are more distinguished initially; infections appear as olive-green spots with indefinite borders. In time, spots become larger and velvety olive-green collared by the lot of conidia. Olive green lesions turn gray brown with distinct margin and lesions are raised. Early infections on the fruits can lead to abnormal growth (fruit deformation) and fruit drop. The lesions on the fruits are similar to those on the leaves. The sepals can be infected early, and from these parts the young fruit can be infected by conidia. Early infections of young fruit can lead to abnormal growth (fruit deformation) and cracking and fruit drop. If the fruit is infected late in the summer or just before harvest, black, circular, very small (0.1 - $4 \mathrm{~mm}$ diameter) lesions called 'pin-point scab' will appear during storage.

\section{Disease control}

Effect of fungicides at different times of application on the severity\% of apple scab at Qalyoubia and Beheira governorates.

The apple scab disease developed early and quickly eventually reaching moderate to severe levels and usually lasts six to seven weeks starting 
approximately at fruit set in the first week of April and ending around the end of June or July. Foliar fungicides were applied four times in an effort to reduce losses due to this disease. One of the most important factors to consider when making a foliar fungicide application is the timing of the application and how long can you expect protection from each fungicide. In Beheira governorate, environmental factors during 2017 and 2018 were favorable for the development of infection apple scab caused by $V$. inaequalis which resulted in $32.60 \%$ disease severity in the first year and $35.46 \%$ disease severity in the second year in control treatment compared with Qalyoubia governorate which the \% disease severities were 27.13 and $29.33 \%$ in the two seasons, respectively. Ten protective and curative fungicides were evaluated for their efficiency for controlling apple scab disease. Also, the experiments were undertaken to compare the effect of four programs according to the time of application on the effectiveness of fungicides for controlling apple scab disease under field conditions in Qalyoubia and Beheira governorates. Data in Tables 2, 3, 4 and 5 show that, the efficiency of the tested fungicides strongly depended on the time of application which markedly affected the efficiency of the fungicides. All the tested fungicides at the third application program (at fruit set in the first week of April) resulted in significant reduction of the disease severity\% where the mean efficiency\% were 77.37 and $76.10 \%$ in Qalyoubia governorate and $75.90 \%$ and $74.44 \%$ in Beheira governorate in 2017 and 2018 seasons, respectively, followed by the second application program (at full bloom in the first week of March) which gave mean efficiency\% 70.10 and $69.25 \%$ in Qalyoubia governorate and $68.86 \%$ and $68.13 \%$ in Beheira governorate in 2017 and 2018 seasons, respectively. Whatever, the first application program (at bud burst in the first week of February) and the fourth application program (at fruit growth in the first week of May) recorded the highest disease severity $\%$ and the lowest efficiency in the two governorates through 2017and 2018 growth seasons. Data also show that, Bellis, Amistar top and Score had high mean efficiency, followed by Occidor, Topsin M, Namrod but the lowest disease efficiency\% were recorded at Dithane $M$, Index, Copper oxychloride and Microvit through 2017 and 2018 growing seasons.

Effect of fungicides at different times of application on the fruit yield (kg/tree) at Qalyoubia and Beheira governorates.

Data in Tables 6, 7, 8 and 9 show that all fungicides increased the average fruit yield (kg/tree) compared with the control. Also the time of application significantly affected the efficiency of the fungicides and increased average fruit yield (kg/tree). High yields were achieved at the third application program (at fruit set in the first week of April) which gave 38.14 and 35.61 mean fruit yield in Qalyoubia governorate and 36.17 and 34.60 mean fruit yield in Beheira governorate in the two seasons, respectively, followed by the second application program (at full bloom in the first week of March) which achieved (33.11 and 31.08) and (31.51 and 30.33) mean fruit yield in Qalyoubia and Beheira governorate in the two seasons, respectively. The lowest mean fruit yield was recorded in the first application program (at bud burst in the first week of February) and the fourth application program (at fruit growth in the first week of May) in the two governorates through 2017 and 2018 growing seasons. Data also show differences among treatments in all trials. Bellis, Amistar top and Score had a high fruit yield, followed by Occidor, Topsin M, Namrod but the lowest fruit yield was recorded with Dithane M, Index, Copper oxychloride and Microvit through 2017 and 2018 growing seasons. 
Table 2. Effect of different application times of ten fungicides on apple scab disease severity of Anna cv in Qalyoubia governorate during 2017 growing season.

\begin{tabular}{|c|c|c|c|c|c|c|c|c|c|}
\hline \multirow[t]{3}{*}{ Treatment } & \multicolumn{8}{|c|}{ Four application programs } & \multirow{3}{*}{$\begin{array}{l}\text { \%Mean } \\
\text { *Eff. }\end{array}$} \\
\hline & \multicolumn{2}{|c|}{$\begin{array}{c}\text { First } \\
\text { application }\end{array}$} & \multicolumn{2}{|c|}{$\begin{array}{l}\text { Second } \\
\text { application }\end{array}$} & \multicolumn{2}{|c|}{$\begin{array}{c}\text { Third } \\
\text { application }\end{array}$} & \multicolumn{2}{|c|}{$\begin{array}{c}\text { Fourth } \\
\text { application }\end{array}$} & \\
\hline & D.S.\% & $\%$ Eff & D.S.\% & $\%$ Eff. & D.S.\% & \% Eff. & D.S.\% & \% Eff. & \\
\hline Microvit & 13.53 & 50.13 & 10.63 & 60.82 & 8.06 & 70.29 & 15.60 & 42.50 & 55.93 \\
\hline Amistar top & 8.60 & 68.31 & 4.20 & 84.52 & 2.53 & 90.67 & 10.60 & 60.93 & 76.11 \\
\hline Bellis & 8.20 & 69.78 & 3.93 & 85.51 & 2.40 & 91.15 & 10.13 & 62.66 & 77.27 \\
\hline Score & 8.60 & 68.30 & 4.40 & 83.78 & 2.80 & 89.67 & 11.13 & 58.98 & 75.18 \\
\hline TopsinM-70 & 8.93 & 67.08 & 5.33 & 80.35 & 3.26 & 87.98 & 11.20 & 58.72 & 73.53 \\
\hline DithaneM-45 & 9.73 & 64.13 & 5.80 & 78.62 & 3.66 & 86.50 & 12.40 & 54.29 & 70.89 \\
\hline Nimrod & 9.07 & 66.56 & 5.47 & 79.84 & 3.53 & 86.99 & 11.46 & $\mathbf{5 7 . 7 6}$ & 72.79 \\
\hline Occidor & 8.66 & 68.08 & 5.20 & 80.83 & 3.40 & 87.46 & 11.00 & 59.45 & 73.96 \\
\hline Index & 11.20 & 58.71 & 8.33 & 69.30 & 5.26 & 80.61 & 13.66 & 49.64 & 64.57 \\
\hline Copper oxychloride & 11.53 & 57.50 & 8.80 & 67.56 & 5.47 & 79.84 & 14.26 & 47.43 & 63.08 \\
\hline control & 27.13 & -- & 27.13 & -- & 27.13 & -- & 27.13 & -- & -- \\
\hline Mean & $11.38 \mathrm{~A}$ & 58.05 & 8.08B & 70.10 & 6.15B & 77.37 & $13.52 \mathrm{~A}$ & 50.21 & 63.93 \\
\hline LSD at 0.05 & & & & & 2.394 & & & & \\
\hline
\end{tabular}

D.S\%= disease severity.

$\%$ Eff. = \% Efficiency.

Table 3. Effect of different application times of ten fungicides on apple scab disease severity of Anna cv in Behiera governorate during 2017 growing season.

\begin{tabular}{|c|c|c|c|c|c|c|c|c|c|}
\hline \multirow{3}{*}{ Treatment } & \multicolumn{8}{|c|}{ Four application programs } & \multirow{3}{*}{$\begin{array}{l}\text { \%Mean } \\
{ }^{*} \text { Eff. }\end{array}$} \\
\hline & \multicolumn{2}{|c|}{$\begin{array}{c}\text { First } \\
\text { application }\end{array}$} & \multicolumn{2}{|c|}{$\begin{array}{c}\text { Second } \\
\text { application }\end{array}$} & \multicolumn{2}{|c|}{$\begin{array}{c}\text { Third } \\
\text { application }\end{array}$} & \multicolumn{2}{|c|}{$\begin{array}{c}\text { Fourth } \\
\text { application }\end{array}$} & \\
\hline & D.S.\% & $\%$ Eff & D.S.\% & \% Eff. & D.S.\% & \% Eff. & D.S.\% & $\%$ Eff. & \\
\hline Microvit & 16.67 & 48.87 & 13.40 & 58.90 & 9.80 & 69.94 & 19.13 & 41.32 & 54.76 \\
\hline Amistar top & 10.47 & 67.88 & 5.66 & 82.63 & 3.87 & 88.13 & 13.60 & 58.28 & 74.23 \\
\hline Bellis & 9.80 & 69.94 & 5.13 & 84.26 & 3.60 & 88.96 & 13.24 & 59.39 & 75.64 \\
\hline Score & 10.80 & 66.87 & 5.86 & 82.02 & 3.97 & 87.82 & 13.93 & 57.27 & 73.50 \\
\hline TopsinM-70 & 11.13 & 65.86 & 6.60 & 79.75 & 4.33 & 86.71 & 14.13 & 56.66 & 72.25 \\
\hline DithaneM-45 & 12.26 & 62.39 & 7.20 & 77.91 & 5.20 & 84.05 & 15.53 & 52.36 & 69.18 \\
\hline Nimrod & 11.26 & 65.46 & 6.73 & 79.35 & 4.73 & 85.49 & 14.26 & 56.26 & 71.64 \\
\hline Occidor & 10.66 & 67.30 & 6.87 & 78.92 & 4.53 & 86.10 & 13.80 & 57.67 & 72.50 \\
\hline Index & 14.27 & 56.23 & 10.67 & 67.27 & 6.73 & 79.36 & 17.06 & 47.67 & 62.63 \\
\hline Copper oxychloride & 14.40 & 55.82 & 10.93 & 66.47 & 7.06 & 78.34 & 17.40 & 46.62 & 61.81 \\
\hline control & 32.60 & --- & 32.60 & -- & 32.60 & -- & 32.60 & -- & -- \\
\hline Mean & $14.03 B$ & 56.96 & $10.15 \mathrm{C}$ & 68.86 & 7.84D & 75.90 & $16.80 \mathrm{~A}$ & 48.50 & 62.56 \\
\hline LSD at 0.05 & & & & & 2.192 & & & & \\
\hline
\end{tabular}

D.S\%= disease severity.

\% Eff. = \% Efficiency 
Table 4. Effect of different application times of ten fungicides on apple scab disease severity of Anna cv in Qalyoubia governorate during 2018 growing season.

\begin{tabular}{|c|c|c|c|c|c|c|c|c|c|}
\hline \multirow{3}{*}{ Treatment } & \multicolumn{8}{|c|}{ Four application programs } & \multirow{3}{*}{$\begin{array}{c}\% \\
\text { Mean } \\
{ }^{*} \text { Eff. }\end{array}$} \\
\hline & \multicolumn{2}{|c|}{$\begin{array}{c}\text { First } \\
\text { application }\end{array}$} & \multicolumn{2}{|c|}{$\begin{array}{c}\text { Second } \\
\text { application }\end{array}$} & \multicolumn{2}{|c|}{$\begin{array}{c}\text { Third } \\
\text { application }\end{array}$} & \multicolumn{2}{|c|}{$\begin{array}{c}\text { Fourth } \\
\text { application }\end{array}$} & \\
\hline & D.S.\% & $\%$ Eff & D.S.\% & \% Eff. & D.S.\% & $\%$ Eff. & D.S.\% & $\%$ Eff. & \\
\hline Microvit & 14.73 & 49.78 & 12.13 & 58.64 & 9.06 & 69.11 & 17.07 & 41.80 & 54.83 \\
\hline Amistar top & 9.40 & 67.95 & 4.73 & 83.87 & 3.26 & 88.85 & 12.06 & 58.88 & 74.88 \\
\hline Bellis & 9.13 & 68.87 & 4.33 & 85.24 & 2.86 & 90.24 & 11.26 & 61.60 & 76.48 \\
\hline Score & 9.53 & 67.51 & 5.06 & 82.74 & 3.33 & 88.64 & 12.46 & 57.51 & 74.10 \\
\hline TopsinM-70 & 9.66 & 67.06 & 5.80 & 80.23 & 4.26 & 85.47 & 12.80 & 56.35 & 72.27 \\
\hline DithaneM-45 & 10.93 & 62.73 & 6.40 & 78.18 & 4.46 & 84.79 & 13.60 & 53.63 & 68.83 \\
\hline Nimrod & 9.93 & 66.14 & 6.20 & 78.86 & 4.33 & 85.24 & 12.80 & 56.35 & 71.64 \\
\hline Occidor & 9.60 & 67.27 & 5.87 & 79.98 & 3.93 & 86.60 & 12.20 & 58.40 & 73.06 \\
\hline Index & 12.73 & 56.59 & 9.60 & 67.26 & 6.06 & 79.34 & 15.13 & 48.41 & 63.40 \\
\hline Copper oxychloride & 12.93 & 55.91 & 9.73 & 66.82 & 6.20 & 78.86 & 15.60 & 46.81 & 62.10 \\
\hline control & 29.33 & -- & 29.33 & -- & 29.33 & -- & 29.33 & -- & -- \\
\hline Mean & 12.54B & 57.25 & $9.05 \mathrm{C}$ & 69.25 & 6.99D & 76.10 & $14.94 \mathrm{~A}$ & 49.06 & 62.88 \\
\hline LSD at 0.05 & & & & & 2.02 & & & & \\
\hline
\end{tabular}

D.S\%= disease severity.

\% Eff. = \%Efficiency.

Table 5. Effect of different application times of ten fungicides on apple scab disease severity of Anna cv in Beheira governorate during 2018 growing season.

\begin{tabular}{|c|c|c|c|c|c|c|c|c|c|}
\hline \multirow{3}{*}{ Treatment } & \multicolumn{8}{|c|}{ Four application programs } & \multirow{3}{*}{$\begin{array}{c}\% \\
\text { Mean } \\
{ }^{*} \text { Eff. }\end{array}$} \\
\hline & \multicolumn{2}{|c|}{$\begin{array}{c}\text { First } \\
\text { application }\end{array}$} & \multicolumn{2}{|c|}{$\begin{array}{l}\text { Second } \\
\text { application }\end{array}$} & \multicolumn{2}{|c|}{$\begin{array}{c}\text { Third } \\
\text { application }\end{array}$} & \multicolumn{2}{|c|}{$\begin{array}{c}\text { Fourth } \\
\text { application }\end{array}$} & \\
\hline & D.S.\% & $\%$ Eff & D.S.\% & \% Eff. & D.S.\% & \% Eff. & D.S.\% & \% Eff. & \\
\hline Microvit & 18.86 & 46.81 & 15.33 & 56.77 & 11.20 & 68.41 & 20.86 & 41.17 & 53.29 \\
\hline Amistar top & 11.86 & 66.55 & 6.20 & 82.51 & 4.73 & 86.67 & 15.20 & 57.13 & 73.22 \\
\hline Bellis & 11.06 & 68.81 & 5.73 & 83.84 & 4.33 & 87.78 & 14.73 & 58.46 & 74.72 \\
\hline Score & 12.06 & 65.99 & 6.46 & 81.78 & 5.13 & 85.53 & 15.26 & 56.96 & 72.56 \\
\hline TopsinM-70 & 12.46 & 64.86 & 7.60 & 78.57 & 5.26 & 85.16 & 15.66 & 55.83 & 71.10 \\
\hline DithaneM-45 & 13.20 & 62.77 & 8.53 & 75.95 & 6.13 & 82.71 & 16.73 & 52.82 & 68.56 \\
\hline Nimrod & 12.86 & 63.73 & 7.67 & 78.36 & 5.80 & 83.64 & 16.00 & 54.88 & 70.15 \\
\hline Occidor & 12.66 & 64.29 & 7.80 & 78.00 & 5.46 & 84.60 & 15.86 & 55.27 & 70.54 \\
\hline Index & 15.67 & 55.81 & 11.40 & 67.85 & 7.93 & 77.64 & 18.80 & 46.98 & 62.07 \\
\hline Copper oxychloride & 16.40 & 53.75 & 12.13 & 65.79 & 8.26 & 76.70 & 19.40 & 45.29 & 60.38 \\
\hline control & 35.46 & -- & 35.46 & -- & 35.46 & -- & 35.46 & -- & -- \\
\hline Mean & $15.60 \mathrm{~B}$ & 55.76 & $11.31 \mathrm{C}$ & 68.13 & 9.07D & 74.44 & $18.55 \mathrm{~A}$ & 47.71 & 61.51 \\
\hline LSD at 0.05 & & & & & 1.597 & & & & \\
\hline
\end{tabular}

D.S\%= disease severity.

$\%$ Eff. = \% Efficiency. 
Table 6. Efficacy of ten fungicides at different times of application on fruit yield ( $\mathrm{kg} /$ tree) of Anna cv in Qalyoubia governorate during 2017 growing season.

\begin{tabular}{|l|c|c|c|c|c|}
\hline \multirow{2}{*}{ Treatment } & \multicolumn{3}{|c|}{ Average fruit yield (Kg/tree) at Four application } & \multirow{2}{*}{$\begin{array}{c}\text { Mean } \\
\text { programs }\end{array}$} \\
\cline { 2 - 5 } & $\begin{array}{c}\text { First } \\
\text { application }\end{array}$ & $\begin{array}{c}\text { Second } \\
\text { application }\end{array}$ & $\begin{array}{c}\text { Third } \\
\text { application }\end{array}$ & $\begin{array}{c}\text { Fourth } \\
\text { application }\end{array}$ & \\
\hline Microvit & 25.33 & 28.33 & 34.00 & 23.66 & $27.83 f$ \\
\hline Amistar top & 32.00 & 38.00 & 43.33 & 29.00 & $35.58 \mathrm{ab}$ \\
\hline Bellis & 33.00 & 39.33 & 44.66 & 29.66 & $36.66 \mathrm{a}$ \\
\hline Score & 31.00 & 37.00 & 41.33 & 28.66 & $34.49 \mathrm{a}-\mathrm{c}$ \\
\hline TopsinM-70 & 30.33 & 36.33 & 41.00 & 27.00 & $33.66 \mathrm{a}-\mathrm{c}$ \\
\hline DithaneM-45 & 28.00 & 33.33 & 39.33 & 25.00 & $31.41 \mathrm{c}-\mathrm{e}$ \\
\hline Nimrod & 29.00 & 34.33 & 40.33 & 26.33 & $32.49 \mathrm{~b}-\mathrm{d}$ \\
\hline Occidor & 29.66 & 35.00 & 40.66 & 27.00 & $33.08 \mathrm{~b}-\mathrm{d}$ \\
\hline Index & 26.66 & 31.33 & 37.33 & 24.33 & $29.91 \mathrm{~d}-\mathrm{f}$ \\
\hline Copper oxychloride & 25.33 & 29.66 & 36.00 & 23.00 & $28.49 \mathrm{ef}$ \\
\hline control & 21.66 & 21.66 & 21.66 & 21.66 & $21.66 \mathrm{~g}$ \\
\hline Mean & $28.36 \mathrm{C}$ & $33.11 \mathrm{~B}$ & $38.15 \mathrm{~A}$ & $25.94 \mathrm{C}$ & 31.38 \\
\hline LSD at 0.05 & & & 3.191 & & \\
\hline
\end{tabular}

There are significant differences among variable letters in the columns

Table 7. Efficacy of ten fungicides at different times of application on fruit yield (Kg/tree) of Anna cv in Behiera governorate during 2017 growing season.

\begin{tabular}{|l|c|c|c|c|l|}
\hline \multirow{2}{*}{ Treatment } & \multicolumn{4}{|c|}{ Average fruit yield (Kg/tree) at Four application } & \multicolumn{1}{c|}{$\begin{array}{c}\text { Mean } \\
\text { programs } \\
\text { Fruit yield } \\
\text { (kg/tree) }\end{array}$} \\
\cline { 2 - 5 } & $\begin{array}{c}\text { First } \\
\text { application }\end{array}$ & $\begin{array}{c}\text { Second } \\
\text { application }\end{array}$ & $\begin{array}{c}\text { Third } \\
\text { application }\end{array}$ & $\begin{array}{c}\text { Fourth } \\
\text { application }\end{array}$ & \\
\hline Microvit & 23.33 & 27.00 & 32.33 & 21.00 & $25.91 \mathrm{e}$ \\
\hline Amistar top & 30.00 & 37.66 & 41.33 & 26.00 & $33.74 a b$ \\
\hline Bellis & 30.66 & 39.33 & 42.00 & 27.33 & $34.83 \mathrm{a}$ \\
\hline Score & 29.00 & 35.00 & 40.00 & 26.33 & $32.58 \mathrm{ab}$ \\
\hline TopsinM-70 & 28.33 & 34.66 & 39.66 & 25.33 & $31.99 \mathrm{a}-\mathrm{c}$ \\
\hline DithaneM-45 & 25.00 & 31.33 & 36.00 & 22.33 & $28.66 \mathrm{c}-\mathrm{e}$ \\
\hline Nimrod & 27.00 & 32.66 & 38.00 & 24.33 & $30.49 \mathrm{~b}-\mathrm{d}$ \\
\hline Occidor & 28.33 & 34.00 & 39.66 & 26.66 & $32.16 \mathrm{a}-\mathrm{c}$ \\
\hline Index & 24.33 & 29.00 & 36.00 & 21.66 & $27.74 \mathrm{de}$ \\
\hline Copper oxychloride & 23.33 & 27.66 & 34.66 & 21.00 & $26.66 \mathrm{e}$ \\
\hline control & 18.33 & 18.33 & 18.33 & 18.33 & $18.33 \mathrm{f}$ \\
\hline Mean & $26.14 \mathrm{C}$ & $31.51 \mathrm{~B}$ & $36.17 \mathrm{~A}$ & $23.66 \mathrm{C}$ & 29.37 \\
\hline LSD at 0.05 & & & 3.299 & & \\
\hline
\end{tabular}

There are significant differences among variable letters in the columns 
Table 8. Efficacy of ten fungicides at different times of application on fruit yield (Kg/tree) of Anna cv in Qalyoubia governorate during 2018 growing season.

\begin{tabular}{|l|c|c|c|c|c|}
\hline \multirow{2}{*}{ Treatment } & \multicolumn{4}{|c|}{ Average fruit yield (Kg/tree) at Four application } & $\begin{array}{c}\text { Mean } \\
\text { programs } \\
\text { Fruit yield } \\
\text { (kg/tree) }\end{array}$ \\
\cline { 2 - 6 } & $\begin{array}{c}\text { First } \\
\text { application }\end{array}$ & $\begin{array}{c}\text { Second } \\
\text { application }\end{array}$ & $\begin{array}{c}\text { Third } \\
\text { application }\end{array}$ & $\begin{array}{c}\text { Fourth } \\
\text { application }\end{array}$ & \\
\hline Microvit & 24.33 & 27.33 & 31.33 & 22.33 & $26.33 \mathrm{e}$ \\
\hline Amistar top & 31.00 & 36.00 & 41.00 & 28.00 & $34.00 \mathrm{ab}$ \\
\hline Bellis & 32.00 & 37.33 & 42.00 & 29.33 & $35.16 \mathrm{a}$ \\
\hline Score & 30.66 & 35.66 & 40.00 & 26.66 & $33.24 \mathrm{ab}$ \\
\hline TopsinM-70 & 29.33 & 33.33 & 38.33 & 25.66 & $31.66 \mathrm{a}-\mathrm{c}$ \\
\hline DithaneM-45 & 25.33 & 30.33 & 35.66 & 23.00 & $28.58 \mathrm{c}-\mathrm{e}$ \\
\hline Nimrod & 27.33 & 33.33 & 37.66 & 24.00 & $30.58 \mathrm{~b}-\mathrm{d}$ \\
\hline Occidor & 28.00 & 34.00 & 39.33 & 26.00 & $31.83 \mathrm{a}-\mathrm{c}$ \\
\hline Index & 24.66 & 28.33 & 34.33 & 23.33 & $27.66 \mathrm{de}$ \\
\hline Copper oxychloride & 24.00 & 26.66 & 32.33 & 22.00 & $26.24 \mathrm{e}$ \\
\hline control & 19.66 & 19.66 & 19.66 & 19.66 & $19.66 \mathrm{f}$ \\
\hline Mean & $26.67 \mathrm{C}$ & $31.09 \mathrm{~B}$ & $35.61 \mathrm{~A}$ & $24.55 \mathrm{C}$ & 29.53 \\
\hline LSD at 0.05 & & & 3.446 & & \\
\hline
\end{tabular}

There are significant differences among variable letters in the columns

Table 9. Efficacy of ten fungicides at different times of application on fruit yield (Kg/tree) of Anna cv in Behiera governorate during 2018 growing season.

\begin{tabular}{|c|c|c|c|c|c|}
\hline \multirow[t]{2}{*}{ Treatment } & \multicolumn{4}{|c|}{$\begin{array}{l}\text { Average fruit yield (kg/tree) at four application } \\
\text { programs }\end{array}$} & \multirow{2}{*}{$\begin{array}{c}\text { Mean } \\
\text { Fruit yield } \\
\text { (kg/tree) }\end{array}$} \\
\hline & $\begin{array}{c}\text { First } \\
\text { application }\end{array}$ & $\begin{array}{l}\text { Second } \\
\text { application }\end{array}$ & $\begin{array}{l}\text { Third } \\
\text { application }\end{array}$ & $\begin{array}{l}\text { Fourth } \\
\text { application }\end{array}$ & \\
\hline Microvit & 22.00 & 26.33 & 30.33 & 20.00 & $24.66 f$ \\
\hline Amistar top & 29.33 & 36.33 & 40.00 & 24.33 & $32.49 a b$ \\
\hline Bellis & 30.33 & 37.66 & 41.66 & 25.33 & $33.74 a$ \\
\hline Score & 28.66 & 34.33 & 39.00 & 23.66 & $31.41 \mathrm{a}-\mathrm{c}$ \\
\hline TopsinM-70 & 27.33 & 33.00 & 37.66 & 23.00 & $30.24 a-c$ \\
\hline DithaneM-45 & 23.66 & 30.66 & 34.33 & 21.00 & 27.41c-f \\
\hline Nimrod & 26.00 & 32.00 & 36.00 & 22.33 & $29.08 b-e$ \\
\hline Occidor & 27.33 & 32.66 & 37.00 & 23.33 & $30.08 a-d$ \\
\hline Index & 22.33 & 27.33 & 34.33 & 21.00 & 26.24d-f \\
\hline Copper oxychloride & 21.00 & 26.33 & 33.33 & 20.33 & $25.24 \mathrm{ef}$ \\
\hline control & 17.00 & 17.00 & 17.00 & 17.00 & $17.00 \mathrm{~g}$ \\
\hline Mean & 24.99 & 30.33 & 34.60 & 21.93 & 27.96 \\
\hline LSD at 0.05 & & & 3.531 & & \\
\hline
\end{tabular}

There are significant differences among variable letters in the columns 


\section{DISCUSSION}

Fungal diseases are the main problem for commercial apple production. They cause root rots, leaf spots, leaf blights, blossom blights, fruit decay, fruit spots, canker and post-harvest decay. The most important disease and destructive pathogen of apple after fire blight caused by Erwinia amylovora is apple scab caused by Venturia inaequalis. It causes economic losses in apple quality and quantity of yield every year. Apple scab (Venturia inaequalis) is usually the main apple fungal disease in commercial apple production in temperate and humid regions. Scab mainly attacks the leaves and fruits (Sandskar, 2003). Holbet al., (2003) estimated apple scab, yield and quality losses in the Netherlands and reported that yield and quality losses were around $80 \%$ if no control measures were taken. Jamar et al., (2010) showed that apple scab infections do not kill the tree but result in leaf and fruit loss with severe defoliation of susceptible cultivars. The direct loss in fruit, apple scab can severely weaken the viability of trees for next season since infections, reduce photosynthesis, woody growth is limited, and fruit bud initiation is prevented or reduced. Also they showed that "during-infection" spray strategy offers valuable advantages for effective apple scab control with a reduced amount of fungicide from 30 to $50 \%$. Apple scab can also continue developing in storage and allow other post-harvest pathogens to establish on fruit (Tomerlin and Jones, 1983). Scab also reduces fruit size or causing premature fruit drop, defoliation and poor fruit bud development of the next year, and it reduces the length of time to infected fruit can be kept in storage Markuet al., (2014). Meszka (2015) reported that in Poland, ascospores are the main source of primary inoculum for apple scab infection during spring. The monitoring of ascospore maturation is therefore important because it can help growers to decide when to apply fungicides during the period when ascospores are matured and released. The greater severity of apple scab was in seasons with a high amount of precipitation during April and May, which corresponded with pink bud and flowering apple phases that were very susceptible to infection.

Apple scab management is most often based on repeated fungicide applications that result in high costs for controlling the disease. This leads to accumulate side effects such as disease resistance, contamination of environment, elevated fungicide residues in fruit, and increased health risks to consumers and workers. To reduce using of fungicides, reduce production costs and maintaining a high crop quality, it is necessary to simplify and optimize apple scab management. Chemical control with fungicides has been recommended as the main tool to control apple scab disease and fungicides are sprayed when there are favorable conditions for disease development. Buhler and Gessler, (1994) reported that up to 20 fungicide treatments is performed per season to control apple scab disease. To control apple scab disease in regions with humid climate up to 14-22 topical spray treatments of fungicides, usually every 7 14 days were needed (Holb et al. 2003). Failure to control disease has been observed in some orchards due to fungicides do not apply at a suitable time. Wasted fungicides during unnecessary applications are not only a problem of controlling the target disease, but compound drift can promote the development of resistance in plant pathogenic fungi in the environment.Apple scab infection was observed at Kafr El Dawar, Beheira governorate in1 ${ }^{\text {st }}$ of April and at El Qanater El-Khairia, Qalyoubia governorate in $7^{\text {th }}$ of April.The effect of 
four application programs according to times of application on the effectiveness of fungicides were compared with controlling apple scab disease to optimize the use of fungicides against scab and to reduce the total spray applications per season on average till four. The efficiency of the fungicides declined when the fungicides were applied through the first application program (at bud burst in the first week of February) and also fourth application program (at fruit growth in the first week of May) compared with the third application program (at fruit set in the first week of April) and second application program (at full bloom in the first week of March) in the two successive seasons. The protection provided by fungicides applied too early in the first application program, the tested fungicides were sprayed at bud burst in the first week of February and too late in the fourth application program (at fruit growth in the first week of May) does not provide the desired level of control. Fungicides applied during these two time periods won't likely be able to stop fungus from developing. Development of the disease lesions after fungicide applications in the first application program or before fungicide applications in the fourth application program may be the main reason of reducing the efficiency of treatments because of the fungicides nearly need 14 days of full protection and another 7 days of partial protection, so they will not protect plants in the two programs. Although fungicide applications too early in the first application program (at bud burst in the first week of February) contributed to the reduction of primary inoculum, it is very important to efficiently control secondary infections later in the season that will increase in number with each new secondary infection during spring. Efficacy of fungicides decreases over time to reach the 'no efficacy level' after 7 to 10 days from fungicide applications; this made the first application program does not suitable to apple growers. A feasible program for growers to control apple scab is the third application program, the tested fungicides were sprayed at fruit set (when $85-90 \%$ of the petals have fallen) in the first week of April, followed by the second application program, where the tested fungicides were sprayed at full bloom (when $50-75 \%$ of blossoms are opened) in the first week of March. Data also clear that, all tested fungicides increased the average fruit yield $\mathrm{kg} /$ tree compared with the control and the time of application significantly affected the efficiency of the fungicides and increased the average fruit yield. The highest fruit yield $\mathrm{kg} /$ tree were achieved in the third application program (at fruit set in the first week of April), followed by the second application program (at full bloom in the first week of March), while the lowest fruit yield was recorded in the first application program (at bud burst in the first week of February) and the fourth application program (at fruit growth in the first week of May) in the two governorates through 2017 and 2018 growing seasons. These results are in agreements with those recorded by Radwan (2011) who found that the highest effect of the tested fungicides in controlling root rots in citrus rootstocks was when fungicides were applied as a soil drench at the same time of transplanting in infested soil, followed by treating soil 15 days after transplanting. However, the lowest effect of the tested fungicides was obtained when the infested soil was drenched with the tested fungicides 30 days after transplanting. Hassan (2015) reported that time of application markedly affected the efficiency of the fungicides for controlling dieback disease of mango. The efficiency of the fungicides declined when the fungicides were applied 
through January - February, compared to their application at March - April; and greatly declined when fungicides were applied in May - June in the first and the second season. Jamar et al., (2007) reported that a variety of fungicides with differing modes of action are available. Apple scab is currently controlled by up to 15-20 applications of protective and curative fungicides during the growing season. Fungicide spray programs are required in most apple-growing regions during spring and summer. Aleksic et al., (2012) reported that about $75 \%$ of the total applications of pesticides applied in the production of apples are for the fungal diseases control of which $70 \%$ is used for apple scab control. Meszka, (2015) stated that over $80 \%$ of the fruits of susceptible cultivars can be damaged if the disease is not controlled. Depending on the risk of disease, 10 to 15 or even more fungicidal applications are usually needed for efficient control.If the timing is right, i.e. not too early since the ascospores are not developed yet and not too late since there could be a disease risk, this might be a feasible method for growers. In organic apple growing scab control is focused on the protective use of sulphur, lime sulphur and copper (Jamar et al., 2007). In commercial apple orchards very, frequent fungicide applications (15-22 annually) are needed to control apple scab, depending on weather conditions, disease pressure and cultivar susceptibility (Holb et al., 2005). Funt et al., (1990) reported that after-infection program can significantly reduce fungicide applications for scab control.

\section{Conclusion}

Fungicides are an important tool for management of apple scab disease; however, their applications need to be optimized to obtain the best results in disease management due to multiple factors such as fungicide efficacy, the risk of resistance development, environmental concerns, pesticide residue in harvest, impact on beneficial organisms. The efficiency of the tested fungicides strongly depended on the time of application. The timing of chemical spray in the third application program (at fruit set in the first week of April) should be the main concern of growers and advisers, since it is very important to the efficacy of sprays and the optimization of applications. This may result in saving for the grower as well as in preventing environmental problems.

\section{REFERENCES}

Agrios, N.G. (2005). Plant pathology/Apple scab.UK, 504-507.

Aleksic, G., T. Popovic, M. Starovic, S. Kuzmanovic, D. Josic, N. Dolovac and D. Postic (2012). Sensitivity of Venturia inaequalis isolates to fungicides with different modes of action. In Proceedings of the International Symposium on Current Trends in Plant Protection, Belgrade, Serbia. Institute for Plant Protection and Environment, 421-427.

Anonymous, (2017). Annual report of Agric. Statistical Dept. Egyptian Min. of Agric. A.R.E.

Bowen J.K., C.H. Mesarich, V.G.M. Bus, R.M. Beresford, K.M. Plummer and M.D. Templeton (2011). Venturia inaequalis: the causal agent of apple scab. Molecular Plant Pathology,12: 105-122.

Buhler, M. and C. Gessler (1994). First experiences with an improved apple scab control strategy. Norwegian Journal of Agricultural Sciences,17: 229-240.

Duncan, D. B. (1955). Multiple ranges and multiple f-test Biometrics, 11:1-42.

Funt, R.C., M.A. Ellis and L.V. Madden (1990). Economic analysis of protectant and disease forecastbased fungicide spray programs for 
control of apple scab and grape black rot in Ohio. Plant Dis.,74: 638-642.

Gladieux, P., X.G. Zhang, D. A.Bastien, R.M. V. Sanhueza and M. Sbaghi (2008). On the origin and spread of the scab disease of apple: out of Central Asia. PLoSONE 3(1): e1455.doi: 10.1371 /journal.pone.0001455.

Gubler, W.D. (2006). UCIPM Pest Management Guidelines, Apple. UC ANR Publication 3432, available at http://www.ipm.ucdavis.edu/PMG/r410 0411.html

Gusberti, M., A. Patocchi, C. Gessler and G.A.L. Broggini (2012). Quantification of Venturia inaequalis growth in Malus $x$ domestica with quantitative realtime polymerase chain reaction. PlantDis,96:1791-1797.

Hassan, M.S.S. (2015). Pathological studies on die back disease of mango and its control. Ph.D. Thesis, Fac. Agric., Moshtohor. Benha Univ., Egypt.pp167.

Holb, I.J., B. Heijne and M.J. Jeger (2003). Summer epidemics of apple scab: the relationship between measurements and their implications for the development of predictive models and threshold levels under different disease control regimes. Journal of Phytopathology, 151(6):335-343.

Holb, I.J., B. Heijne, J.C. Withagen, J.M. Gáll and M.J. Jeger (2005). Analysis of summer epidemic progress of apple scab at different apple production systems in the Netherlands and Hungary. Phytopathology, 95(9): 10011020.

Jamar, L., B. Lefrancq and M. Lateu (2007). Control of apple scab (Venturia inaequalis) with bicarbonate salts under controlled environment. Journal of Plant Diseases and Protection, 114(5): 221-227.

Jamar, L., M. Cavelier and M. Lateur (2010). Primary scab control using a "during infection" spray timing and the effect on fruit quality and yield in organic apple production. Biotechnol. Agron. Soc. Environ, 14: 423-439.

Jobin, T. and O. Carisse (2007). Incidence of myclobutanil and kresoxim-methyl insensitive isolates of Venturia inaequalis in Quebec orchards. Plant Disease, 10: 1351-1358.

MacHardy, W.E. (1996). Apple scab: biology, epidemiology, and management. Am. Phytopath. Soc., St. Paul, Minnesota. 545pp.

Marku, L., H. Vrapi and M. Hasani (2014). Effect of potassium bicarbonate (Armicarb) on the control of apple scab (Venturia inaequalis) in the region of Puka in Albania. Internat. Ref. J. of Eng. and Sci. 3, Issue 6.

Meszka, B. (2015). Study of Venturia inaequalis pseudothecia development and apple scab severity under Polish conditions. Folia Hort, 27(2): 107-114.

Radwan, M.A. (2011). Evaluation of efficiency of chemical and biological control of root rots in citrus rootstocks. Ph.D. Thesis, Fac. Agric., Al-Azhar Univ., Egypt. pp167.

Sandskar, B. (2003). Apple scab (Venturia inaequalis) and pests in organic orchards. PhD. thesis, Swedish University of Agricultural Sciences, Sweden.

Snedecor, G.W. and W.G. Cochran (1984). Statistical Methods. lowa State University Press, 9th Ed., 503pp.

Thakur, K., V. Chawla, S. Bhatti, M.K. Swarnkar and J. Kaur (2013). De Novo transcriptome sequencing and analysis for Venturia inaequalis, the devastating apple scab pathogen. PLoS ONE 8(1): e53937. doi: 10.1371/journal.pone.0053937

Tomerlin, J.R. and A.L. Jones (1983). Development of apple scab on fruit in the orchard and during cold storage. Plant disease, 67(2):147-150.

Townsend, G.R. and J.V. Heuberger (1943). Methods for estimating losses caused by diseases in fungicides experiments. Plant Disease Report, 24:340-343. 
تحديد التطبيق الأمثل للمبيدات الفطرية لمكافحة مرض جرب التفاح في مصر

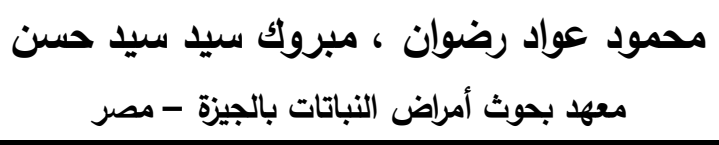

الملخص العربى

مرض جرب التفاح المتسبب عن الفطر فنتوريا إينكواليس من أخطر الأمراض الفطرية التي تصيب أثجار التفاح في

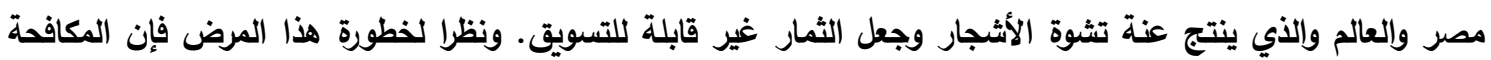

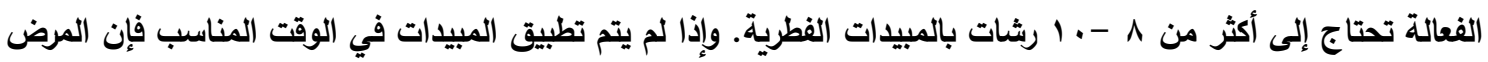

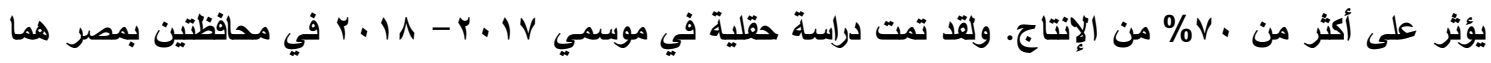

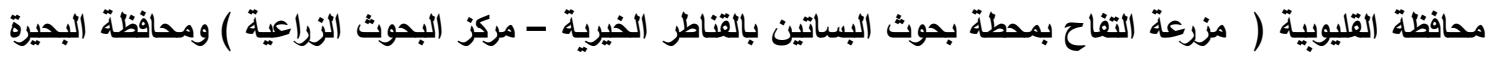

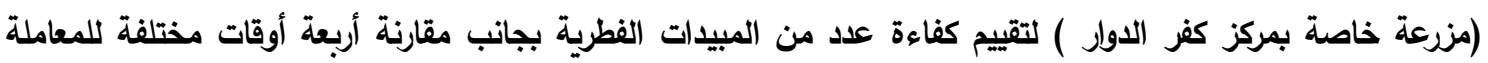

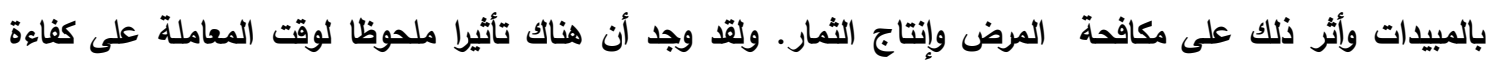

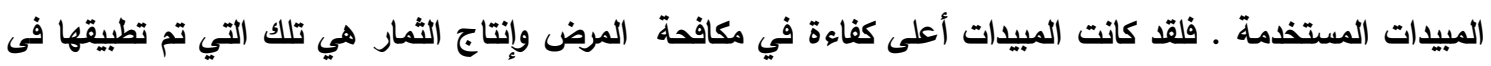

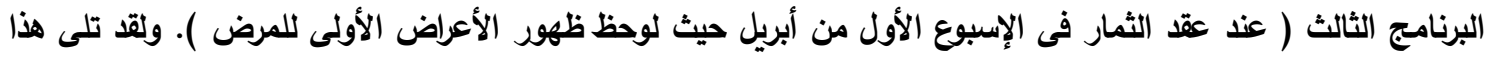

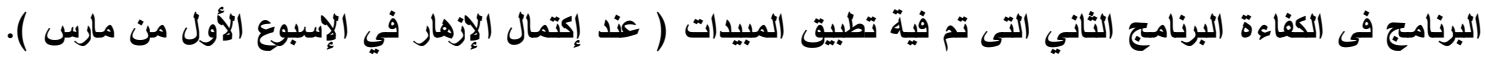

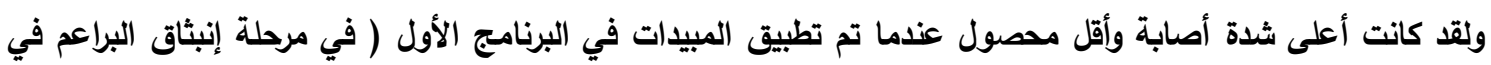

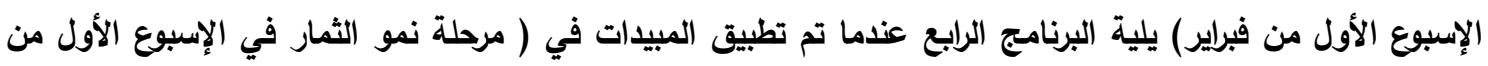

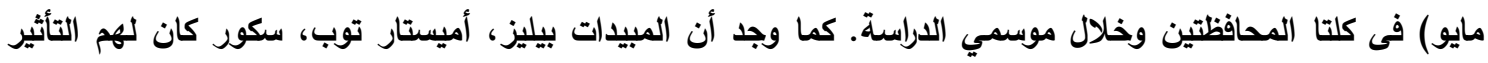

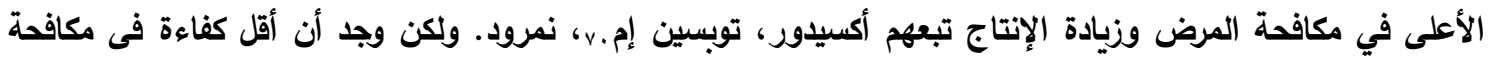

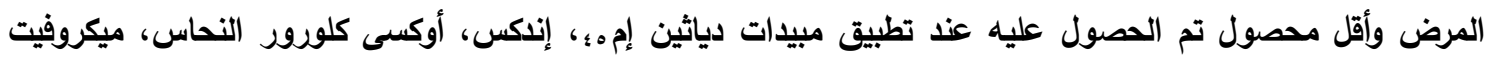

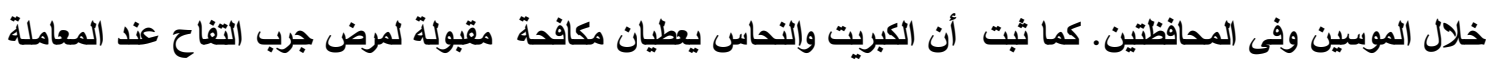
بهما في الوقت المناسب.

كلية الزراعة بمشتهر - جامعة بنها 
